\title{
"Aneurysmal Bone Cyst of the Pelvis: A Systematic Literature Review"
}

Ayesha Saeed ( $\nabla$ drayeshasaeed@gmail.com)

The Children's Hospital and the Institute of Child Health, Faisalabad https://orcid.org/0000-0002-1969-5725

Elke Rometsch

Inserm U1061

Anahí Hurtado-Chong

AO Clinical investigation \& Documentation Unit

\section{Review}

Keywords: Aneurysmal Bone Cyst, pelvis, benign, bone tumors

Posted Date: August 11th, 2020

DOI: https://doi.org/10.21203/rs.3.rs-38828/v1

License: (c) (i) This work is licensed under a Creative Commons Attribution 4.0 International License. Read Full License 


\section{Abstract}

\section{Background:}

Aneurysmal bone cysts $(A B C)$ are rare benign, vascular, osteolytic bone lesions. Pelvic ABCs account for $8-12 \%$ of these tumors and no clear guidelines for their treatment are available. To our knowledge, this is the first systematic literature review regarding pelvic ABCs. Our primary objective was to identify treatment modalities and to assess the bone healing, measured as the degree of radiological ossification. Secondary objectives were to describe demographics, tumor characteristics, clinical and functional outcomes and recurrence.

\section{Methods:}

Searches were conducted in PubMed, Cochrane Library, and Web of Science. Based on the scarcity of reports, inclusion criteria were kept broad and comprised primary or recurrent pelvic $\mathrm{ABCs}$, with a minimum follow up of one year and available information on radiological ossification. Data was extracted on the individual patient-level and grouped according to treatment modality.

\section{Results:}

Forty-nine studies reporting on 194 patients were included. The level of evidence was low (29 case reports and 20 retrospective case series) and the reporting of outcomes inconsistent. Patients had a median age of 15 years and $52 \%$ were male. Five major treatment groups were identified and divided into 11 subgroups. The largest subgroup was curettage (23\%) followed by selective arterial embolization (20\%). Most ABCs were located in the ilium. Variations in mean tumor size (4.5-22.2cm) and degree of ossification (60-100\%) depended on the treatment modality. Overall, in $77 \%$ cases the cyst ossified completely. Recurrence was reported in 22 patients (11\%) and 2 patients (1\%) died during the course of the treatment.

\section{Conclusion:}

Despite the low quality of reporting, this systematic review provides the first comprehensive overview of pelvic ABC treatment modalities and their radiological and clinical outcomes. Neoadjuvant sclero-embolic treatments appear to be used most in recent years, but further comparative studies and better quality of reporting are needed to determine their effectiveness. Quality of reporting should be improved by following reporting guidelines.

\section{Level of Evidence: IV}

\section{Background}

Aneurysmal bone cysts (ABC), also known as "Jaffe-Lichtenstein disease" [1-3], are rare benign non-neoplastic vascular lytic lesions of the bone of unknown etiology[4,5]. The annual incidence of $A B C$ in all bony locations has been reported as 0.14 per 100,000 people; with slight female preponderance[6]. However, the true incidence is difficult to calculate because of the existence of spontaneous regression and clinically silent cases[6]. Eighty percent of $A B C$ occur within the first and second decade of life [7,1]. The clinical course is sometimes unpredictable and local recurrences are relatively often [10], with reported recurrence rates from $5 \%$ to $40 \%[1,11,12]$.

A study describing the anatomical distribution of $897 \mathrm{ABC}$, found pelvic lesions in $11.6 \%$ of the cases, the fourth most frequent site in descending order after tibia, femur and vertebra[8]. In spite of accounting for nearly half of all flat bone lesions[9], pelvic $A B C$ are extremely rare. Management of pelvic $A B C$ requires careful consideration to special factors, like the risk of bleeding, proximity to neurovascular structures, relative inaccessibility, and damage to the integrity of weight bearing structures like the acetabulum or sacrum [10-12].

Several treatment modalities have been reported in the scarce literature available concerning pelvic ABC. We performed a systematic literature review with the primary aim of analyzing the main treatments used for this particular disease and their radiological ossification outcomes. The secondary aims were to describe the demographics, tumor location, clinical and functional outcomes, complications, and recurrence rate.

\section{Methods}

A systematic review of literature on pelvic ABC was conducted on $28^{\text {th }}$ of September 2017 and reported following the PRISMA (Preferred Reporting Items for Systematic Reviews and Meta-Analyses) statement $[13,14]$.

Electronic searches were conducted in PubMed, the Cochrane Library, and Web of Science. The search strategy used a combination of the following terms: ((pelvis OR pelvic) AND (aneurysmal bone cyst [MeSH Terms] OR "aneurysmal bone cyst")). Additional articles were identified by hand searching the reference lists of relevant articles like large case series or literature reviews. A first survey of the identified literature revealed that it was limited to retrospective case series and case reports that in most cases provided information at individual patient level. The eligibility criteria used for this systematic review were:

Inclusion criteria:

1. Primary or recurrent aneurysmal bone cyst located in the pelvis

2. Any age

3. Any treatment method (including observation)

4. Minimum follow up of one year

5. Radiological, clinical and functional outcomes provided by treatment method 
6. Mention of ossification status

7. English language

Exclusion criteria:

1. Secondary pelvic aneurysmal bone cysts

2. Information on treatment or outcome for pelvic tumors was not specified

No date limits were applied. Screening and eligibility assessment was performed by the first author. Neither prospective nor comparative studies met the eligibility criteria. Due to the study designs and level of evidence found, data either on individual patients or grouped by treatment was extracted. The articles' title, publication year, authors and number of patients with pelvic $A B C$ was recorded. Articles describing $A B C$ in multiple locations but containing pelvic zone cases within their study population were included as well and only relevant information related to pelvic $A B C$ was used.

Whenever possible, individual patient information on gender, age, location of ABC according to Enneking and Durham anatomic pelvic zones [15], primary or recurrent $A B C$, tumor size, Enneking staging[16], type of treatment and years of follow-up was recorded.

Rossi et al described the age grouped into 4 categories so it was excluded for the calculation of the mean age [17]. The pelvic zones according to Enneking and Durham[15] used to describe tumor location were: $1=$ ilium, $2=$ acetabulum, 3 = ischium-pubis, $4=$ sacrum. If a tumor extended over more than one zone, the affected zones were combined into a separate category. Given the different ways of measuring and reporting tumor sizes used in the literature, the mean size was calculated using the maximum dimension reported.

The treatment and the outcomes for pelvic $A B C$ reported in the studies presented a high degree of heterogeneity. After reviewing the extracted data, treatment modalities were categorized into the following groups and subgroups for the qualitative synthesis of results:

1. Observation

2. Adjuvant treatment

1. Selective arterial embolization

2. Sclerotherapy

3. Radiotherapy

4. Selective arterial embolization + Sclerotherapy

3. Minor surgery

1. Curettage

2. Extended curettage

4. Major surgery

1. Marginal excision

2. Wide excision

5. Combined

1. Adjuvant + minor surgery

2. Adjuvant + major surgery

The primary outcome was radiological ossification, defined as either "no evidence of disease" or "complete consolidation of the lesion" with or without exogenous material. 'Partial ossification' was considered when terms such as "cystic residues" "partial ossification between $25 \%$ to $75 \%$ ", or "healed with small and large residual geodes" were used. 'No ossification' was considered for terms like "little ossification defined as ossification of <25\%" [17], or "no healing" and "no progression of lesion and no healing" [12].

There was a large degree of imprecision and inconsistency in the terms used to describe clinical outcomes. Therefore patients were considered 'Functional' if they were reported as "functional", "able to perform activities of daily living", "having full range of motion" or with "no functional restrictions". 'Mild and moderate functional derangement (FD)' were considered when similar terms were found [10]. 'Severe FD' was considered for terms like "bladder and bowel dysfunction"[18], "postoperative absent bowel and bladder function"[19], or "patient's functional ambulation was markedly compromised"[20].

Pain severity was categorized into 'mild', 'moderate' or 'no pain'. 'Recurrence' was considered as reappearance of the tumor in the radiographs at least 6 weeks after intervention. Terms such as "disease free", "tumor free", or "no recurrence seen", were considered as 'no recurrence'.

The information available on radiological and clinical outcomes was summarized according to the treatment method. Whenever information on the variables collected was not specified in the article, it was documented as not reported (NR).

The quality and study design of the articles included in this systematic review did not allow a meta-analysis. Summary measures, synthesis of results, risk of bias across studies, publication bias, treatment effect and heterogeneity assessment could not be performed. Given the low level of evidence available, a formal quality assessment was not considered necessary. 
Individual patient data was aggregated according to treatment received and descriptive statistics were applied using "StataCorp 2017".

\section{Results}

A total of 143 records were identified through database searching and cross referencing retrieved articles. After removing duplicates, 123 records were screened for eligibility (Fig 1). After reviewing the title and abstracts, 55 records were excluded. From the remaining 68 records, full-text articles were reviewed for eligibility and further 19 were omitted. Amongst the 19 excluded articles, 16 did not report on any outcomes for specific treatment of pelvic ABC and 3 had a follow up of less than one year.

The final number of studies included in the systematic review was 49, of which 29 were case reports and 20 were case series, spanning from 1979 to 2017. From the 49 studies, data of 194 patients was extracted into an excel sheet.

\section{Treatment groups and patients included per study}

A large number of treatment options was identified and grouped into 5 major treatment groups: observation, adjuvant, minor surgery, major surgery and combined. These major treatment groups were further subdivided into eleven distinct treatment subgroups. The number of studies and patients included in each treatment group are described in Table 1. Some studies appear in more than one treatment group.

Within the 5 major treatment groups, more than half of the patients $113 / 194$ (58\%) were treated either with adjuvant $57 / 194$ (29\%) or minor surgery $56 / 194$ (29\%) whereas observation was the least used treatment accounting for only $13 / 194$ ( $7 \%$ ) patients.

Looking at treatment subgroups, most patients were treated with curettage 45/194 (23\%) followed by selective arterial embolization (SAE) 38/194 (20\%). Amongst the latter, 18 (47\%) patients had only one SAE session, 10 (26\%) patients had two and further 10 patients had three sessions of SAE. Diverse biomaterial like gel foam, latex particles, biospheres, Isobutyl 2 cyanoacrylate (IBCA), polyvinyl alcohol (PVA) and stainless-steel coils were used for the embolization.

Marginal excision was the third most commonly used treatment 27/194 (14\%) whereas wide excision was used only in 5 cases. The terms marginal and wide derive from the 'Enneking classification of surgical margins' which is a standard reported measurement of surgical margins in osseous and soft tissue tumor surgery [25]. Various materials have been described to fill the bony voids after major or minor surgery like autologous bone grafts, allografts, bone cement, bioactive glass, plexur $\mathrm{M}$ biocomposite, arthrodesis with plating and vascularized fibular graft.

The combined treatment groups included any type of surgery along with either SAE, sclerotherapy or radiotherapy. The combined group minor surgery + adjuvant was the fourth most used treatment (26/194). Most of these patients received SAE as neoadjuvant treatment.

Extended curettage was used in 11/194 cases and reportedly done through high speed burr, phenol, or ethanol washes. Sclerotherapy (10/194 cases) was either performed percutaneous or through a mini open approach under fluoroscopy and general anesthesia. The sclerosants used were ethibloc, demineralized bone matrix (DBM) combined with autologous bone graft, $32 \mathrm{P}$ chromic phosphate and polidocanal. The least used methods included radiotherapy (5/194), wide excision (5/194) and SAE with sclerotherapy (4/194). Radiotherapy has been used as neoadjuvant but also as adjuvant and treatment for recurrence. The maximum dosage received by any patient was 6000 Gy (Gray).

Demographics, radiological and functional outcomes were summarized according to the treatment subgroup.

\section{Demographics:}

Patient demographics per treatment subgroup are described in Table 2. From the 194 patients, 91 (47\%) were females, 101 (52\%) were males and gender was not reported for $2(1 \%)$ patients. The overall median age was 15 years, ranging from 1.5 to 64 years old. The median age among the different treatment subgroups was very similar and within the second decade of life except for the wide excision group.

The mean time from the start of the symptoms to diagnosis was 10 months with a range from 2 weeks to 10 years. The median follow up was 3 years, with the longest follow up of 53 years in a 10-year-old with stage $2 \mathrm{ABC}$ in the sacrum treated with extended curettage and radiotherapy [10].

\section{Tumor characteristics:}

Main tumor characteristics in terms of size, anatomic location within the pelvis and Enneking staging according to treatment group and subgroup are described in Table 3. Only 8 (4\%) patients presented with a recurring ABC and the rest were all primary de novo lesions.

The information on tumor size for individual patients was available for only 50/194 patients (25\%); but for 22 (11\%) patients, tumor size was described in categories of less than, up to, or greater than $5 \mathrm{~cm}$ [17]. The minimum reported tumor size was $3 \mathrm{~cm}$ and the maximum $30 \mathrm{~cm}$. Treatment groups with an average size above $15 \mathrm{~cm}$ were all surgical (either as standalone treatment or combined with adjuvant therapy) whereas tumors in the observation group were on average $4.5 \mathrm{~cm}$ and were followed up with a median of 2.8 years.

Most tumors (126/194) were located within one pelvic zone, with a majority of them in the ischio-pubic area (zone 3). Only 13/194 occupied three zones: ilium, acetabulum and ischiopubic area in all except one case (zones 1+2+3). The most frequent combination for tumors within two zones was acetabulum and ischiopubic area (zones $2+3$ ) followed by ilium and acetabulum (1+2), and ilium and ischiopubic (zones $1+3$ ). Tumors involving both ilium and sacrum (zones 1+4) were found only in 4 cases. 
The Enneking staging divides benign bone tumors into 3 categories: latent (stage 1), active (stage 2), and aggressive (stage 3)[21]. Over 50\% of the cases were Enneking stage 3 and $30 \%$ were stage 2. The staging was not mentioned for 30 (15\%) patients.

\section{Outcomes:}

Radiological and clinical outcomes per treatment group are detailed in Table 4. Given that the radiological and functional outcomes reported in the retrieved studies were remarkably inconsistent, heterogenous and in occasions extremely vague, we tried to categorize the outcomes following our best interpretation and understanding of what was reported by the authors. Only one study [11] described the outcomes using the musculoskeletal tumor rating scale (MSTS), Toronto extremity salvage score (TESS) and the 36 item short form health survey (SF-36).

Our primary outcome focused in the ossification. In total,116 patients (60\%) had complete ossification, 19 patients (10\%) had partial and 5 patients ( $2 \%)$ had no evidence of ossification. The ossification status was not available in 20/194 cases: in 18 patients (9\%) it was not reported, and two patients died during or shortly after surgery.

Clinical outcomes related to function, pain and recurrence. Patients were reported as functional in 140 (72\%) cases, mild functional derangement was seen in 11 patients (6\%), moderate in $6(3 \%)$, severe in $4(2 \%)$ and in $41(21 \%)$ the functional outcome was not reported.

At the end of the follow up, 112 patients (58\%) had reportedly no pain, whereas mild pain was mentioned in 16 ( $8 \%$ ) patients, moderate pain in 5 ( $2 \%)$ patients, and in 50 patients (30\%) pain was not reported

Overall, the incidence of recurrence was low. Recurrence was reported in 21 (10.8\%) patients and not reported in 15 patients (8\%), whereas the remaining patients had no recurrence at the time of the last follow up. The longest time to recurrence was 6 years in a 13-year-old male patient with an $A B C$ in the pubis extending to acetabulum treated with extended curettage [10]. Recurrence was treated mostly by curettage or excision and autologous bone grafting. Few recurrent cases were managed with sclero-embolic treatments instead of surgery[22] and 3 cases were treated with radiotherapy[23,24]. Curettage had a relatively high number of recurrences compared to the other treatments, however the unbalanced group size and low number of patients in some subgroups precludes a proper statistical analysis.

The number of reported complications is low. Hemorrhage was reported in $6(3 \%)$ patients who were treated with surgery (5 patients) and sclerotherapy (1 patient). Of these, one patient died secondary to massive bleeding. Neurological complications were described in 13 (7\%) patients and include hypoesthesia, bowel and bladder dysfunction or residual loss of bowel, bladder control, neuroma formations, and involvement of sacral roots, sciatic nerve, obturator nerve and caudal sac. 11 (6\%) patients with neurological complications had ABC located in zone 4 (sacral) while in the remaining 2 were in zones 2 and 3 . One patient with a tumor in zone 2 and 3 had partial encasement of the bladder with the ABC mass resulting in subtotal cystectomy. Leg length discrepancy (0.6 $3 \mathrm{~cm}$ ) was reported in 4 patients (2\%) after marginal resection of ABC. Curettage in the sacrum (pelvic zone 4 ) was performed in 12 (26\%) cases and had frequent reports of hemorrhage, bowel injury, dural tear and loss of bowel bladder control. 9/21(42\%) patients had complications after treatment for recurrence. Capana et al reported 3 of these cases in which the primary treatment was radiotherapy or combination of radiotherapy with surgery, recurrence was observed and treated with curettage or radiotherapy. These patients were left with residual complications of crural nerve palsy, quadriceps, psoas deficit and femoral head necrosis[19].

In this series of 194 cases reported in the literature, two patients died of treatment-related complications. A 51 -year-old female with a $25 \times 25 \times 20 \mathrm{~cm}$ ABC in the right ilium extending into the ischium. The patient was treated surgically and died of profuse perioperative bleeding [25]. The second case was a 48-yearold female with a $27.6 \times 22.4 \times 15.9 \mathrm{~cm}$ lesion in the left ilium with a history of embolization, sclerotherapy and repeated surgery. The authors performed preoperative embolization and percutaneous intralesional alcohol injection followed by staged near total resection combined with cryosurgery and off label systemic treatment with bevacizumab, a monoclonal anti-vascular endothelial growth factor (VEGF) antibody, to reduce bleeding. The patient developed clinical heart failure, prompting discontinuation of bevacizumab followed by a rapid regrowth of the pelvic lesion. After seven surgical sessions, the patient's condition no longer allowed further interventions and she was treated with radiotherapy. The patient died 2 years after ABC was first diagnosed [26].

Aneurysmal bone cyst in the pelvis has also been described in 2 pregnant women. A pelvic bone lesion in pregnancy can be a difficult situation for the obstetrician to determine the effect of parturition on the pelvic bone[27]. The first reported case was in 1986 of a right iliac aneurysmal bone cyst measuring $15 \mathrm{~cm}$ in a 19-year-old primigravida. At the time of the elective caesarian, the mass was excised through a separate lumbar approach. No recurrence or complication was reported[28]. The second reported case was a $6.1 \times 2.9 \times 6 \mathrm{~cm}$ lesion in the left ilium of a 26 -year-old primigravida who had a successful elective caesarian section and the $\mathrm{ABC}$ was observed until the last follow-up[27].

We further analyzed tumor characteristics, clinical and radiological outcomes according to their pelvic zone location and the results are summarized in Table 5. While zone 3 was overall the most common tumor location 48/194 (25\%), when taking in consideration tumors with overlapping zones as well, most patients 74/194 (38\%) had affection of zone 1 - ilium; of these 14 had partial ossification and the functional outcome was not reported in half of them. Tumors in zone 4 sacrum had more neurological complications reported like bladder and bowel dysfunction[18]. Moderate residual pain was mentioned in 4/194 patients located in zones 4, 2+3 and 1+2+3. Moreover severe FD reported in 4/194 were located in zone 4 (3 cases) and zone 1+3 (1 case).

\section{Discussion}

Pelvic aneurysmal bone cyst is a treatment challenge. Most cases have been managed with individualized treatment plans tailored to their size, stage, location, behavior, available clinical resources and surgical expertise. In this systematic literature review we were able to successfully categorize these varied treatments for 194 patients of pelvic $A B C$ in 5 groups and 11 sub-groups which is not only a useful overview of existing therapeutic modalities but also suggests the variability that exists about choosing best treatment modality. 
We were able to identify only 194 patients of pelvic ABC fulfilling our inclusion criteria since 1979, which emphasizes the rarity of the problem. The gender distribution of pelvic $A B C$ in our study had a slight male predominance with $52 \%$ of the cases, which is contrary to previous reports which had a higher prevalence in women. The median age was 15 years although the range was quite wide from 1.5 years to 65 years. Most lesions grow significant size, become stage 3 and remain asymptomatic before being diagnosed. Amongst the 194 reported in literature $60 \%$ show complete radiological ossification, $72 \%$ were reported functional and $10.8 \%$ had a recurrence. These results indicate that most pelvic $A B C$ have a good prognosis.

Curettage with bone grafting is the most preferred treatment method followed by selective arterial embolization either alone or in combination with surgery. In the curettage treatment group $75 \%$ had radiological ossification with no pain and $88 \%$ were 'functional' after treatment $[10,11,29,19,18]$. It was used in all pelvic zones and for any tumor stage. The maximum reported size for a lesion treated with curettage was $30 \times 30 \times 20 \mathrm{~cm}$ in zone 4 in a 14 year old [24].

Selective arterial embolization is described in the literature as a simpler, cheap, easily repeatable, a less invasive or risky procedure. It has been used in patients at extreme ages, the youngest being 1.5 and oldest 64 years. Surgery and radiotherapy were the main treatment modalities for ABC until the introduction of SAE[30]. The earliest records of selective arterial embolization (SAE) for pelvic ABC come from Wallace et al (1979) in 2 patients. They reported $15 \%$ reduction in size and pain free status after one year in one 27 year old female patient with an ABC in ilium. The second patient, a 38 year old male, was reported to have a surgery and cordotomy followed by SAE. The patient remained pain free at 5 years follow-up but had a recurrence later [31].

Varshney et al did a comparative study to determine the healing rate and functional score between two groups treated either with sclerotherapy (polidocanal) or with intralesional curettage. They concluded, that "although the healing rates were similar, we found higher rates of clinically important complications, worse functional outcomes, and higher hospital burden associated with intralesional excision". They called it a preliminary study and recommended larger studies to confirm their findings [32]. In this review comparison of the two groups is not possible due to large discrepancy in patient number 45 in curettage vs. 10 in sclerotherapy group. Moreover due to poor quality of reporting outcomes, the reliability of the results is questionable.

In most recent studies reviewed, sclero-embolic procedures are used as adjuncts or combined with major surgical procedures in large pelvic tumors $[33,32,34,35]$. Papagelopoulos et al set $5 \mathrm{~cm}$ as a cut off for performing a curettage or excisional surgery [10]. We observed in the systematic review that tumors $>15 \mathrm{~cm}$ were all treated surgically either alone or combined with adjuvants. However we cannot say if this is the best treatment in such cases. Following an excisional surgery some major mechanical complications are reported, like hip dislocation/subluxation, protusio acetabuli, limb length discrepancy etc [10]. but according to the reports, the key to overcome these issues is to get a near anatomic reconstruction of the pelvic defects. Currently triradiate iliac crest grafts, vascularized or non-vascularized fibular grafts, allografts, custom-made mega prosthesis, extracorporeal irradiated pelvic bone and re-implantation have all been described[20,18,36-38]. Zidzislaw et al predicts that the future for pelvic defects is statistical shape model (SSM) reconstruction method using mirroring approach.

Since the anatomic location of the tumor influences the treatment strategy and prognosis, we analyzed the results by pelvic zone. Patients with tumors in zone 4 accounted for most of the neurological complications reported whereas half of the cases with hemorrhage, including a deadly case were located in zone 1. In their series of 13 pelvic $A B C$ in children Novais et al observed higher recurrence rates in open physis and suggested that destructive lesions in triradiate cartilage can lead to long term complications [11]. In our results we observed that $3 / 4$ patients with leg length discrepancy were near the triradiate cartilage ie zones 2 and 3. In summary, the particular neighboring structures and their involvement require modified treatment methods for better outcome as Papagelopolus concludes [10].

The minimum average tumor size per treatment group was $4.5 \mathrm{~cm}$ (observation), whereas the maximum average size was $22.5 \mathrm{~cm}$ (curettage); however when the results are grouped by pelvic zones the average diameter ranges only from 7.5 to $15.5 \mathrm{~cm}$. This might suggest that in addition to the anatomic location, the tumor size also has some influence on the treatment method since the average size by pelvic zone is similar. However given that tumor size was only available for $25 \%$ patients these results should be interpreted with great caution.

The limitations of our systematic literature review are mainly due to the low evidence found, which was mostly restricted to retrospective case reports and case series. This was further hampered given the heterogeneous reporting and inconsistent outcome measurements which precluded a metaanalysis.

\section{Conclusion}

Pelvic $A B C$ has been documented in medical literature as case reports or case series and with heterogeneous reporting. In this systematic literature review, individual patient data was extracted to give an overview regarding functional and radiological outcomes by treatment modality.

Although mostly benign, pelvic $\mathrm{ABC}$ has an unpredictable behavior. A clear trend is being adapted towards the use of neo adjuvant sclero-embolic treatments alone or combined with surgery for better radiological and functional outcome. Furthermore, we encourage reporting of surgical case reports following a standard reporting guideline like SCARE statement (http://www.scareguideline.com/) to strengthen the quality of reporting [39,40]

\section{Abbreviations}

$\mathrm{ABC}$ - Aneurysmal Bone Cyst

DBM - Demineralised Bone Matrix

FD - functional derangement

Gy - Gray 
IBCA - Isobutyl 2 cyanoacrylate

MeSH - Medical Subject Heading

MSTS - Musculoskeletal tumor rating scale

NR - Not Reported

PRISMA - Prefered Reporting In Systematic Reviews and Metaanalysis

PVA - Polyvinyl alcohol

SAE - Selective Arterial Embolization

SCARE - Surgical Case Report Guidelines

SSM - Statistical Shape Model

TESS - Toronto Extremity Salvage Score

VEGF - Vascular Endothelial Growth Factor

\section{Declarations}

\section{- Ethics approval and consent to participate}

Not applicable since it's a review of published case reports and case series

\section{- Consent to publish}

Not applicable since it's a review of published case reports and case series

\section{- Availability of data and materials}

The datasets used and/or analysed during the current study are available from the corresponding author on reasonable request

\section{- Competing interests}

The authors declare that they have no known competing financial interests or personal relationships that could have appeared to influence the work reported in this paper.

\section{- Funding}

The present research work was supported by AOTrauma in the form of clinical research fellowship at AOCID granted to the first author. The data collection and manuscript writing was done at AOCID with the help of the supervisor and staff.

\section{- Authors' Contributions}

Ayesha performed the literature review and extracted the data with the constant help of Elke and Anahi. The manuscript was written and edited by all three authors. All authors read and approved the final manuscript.

\section{- Acknowledgements}

We are grateful to AOCID staff, and in particular to Vasiliki Kalampoki for her help in data analysis. We also acknowledge the contribution of Prof Syed Muhammad Awais Dean Faculty of Health Sciences, University of Punjab, Lahore Pakistan for his generous sharing of knowledge, constant support, and for being a source of inspiration.

\section{- Authors' Information}

AS Ayesha Saeed drayeshasaeed@gmail.com, ER Elke Rometschelke.rometsch@aofoundation.org, AHC Anahí Hurtado-Chong anahi.hurtado@aofoundation.org 


\section{References}

1. Mankin HJ, Hornicek FJ, Ortiz-Cruz E, Villafuerte J, Gebhardt MC (2005) Aneurysmal bone cyst: a review of 150 patients. Journal of clinical oncology : official journal of the American Society of Clinical Oncology 23 (27):6756-6762. doi:10.1200/jco.2005.15.255

2. Jaffe HL, Lichtenstein L (1942) Solitary unicameral bone cyst: With emphasis on the roentgen picture, the pathologic appearance and the pathogenesis. Archives of Surgery 44 (6):1004-1025. doi:10.1001/archsurg.1942.01210240043003

3. Jaffe HL (1950) Aneurysmal bone cyst. Bulletin of the Hospital for Joint Diseases 11 (1):3-13

4. Vergel De Dios AM, Bond JR, Shives TC, McLeod RA, Unni KK (1992) Aneurysmal bone cyst. A clinicopathologic study of 238 cases. Cancer 69 (12):29212931

5. Szendroi M, Cser I, Konya A, Renyi-Vamos A (1992) Aneurysmal bone cyst. A review of 52 primary and 16 secondary cases. Archives of orthopaedic and trauma surgery $111(6): 318-322$

6. Leithner A, Windhager R, Lang S, Haas OA, Kainberger F, Kotz R (1999) Aneurysmal bone cyst. A population based epidemiologic study and literature review. Clinical orthopaedics and related research (363):176-179

7. Zehetgruber H, Bittner B, Gruber D, Krepler P, Trieb K, Kotz R, Dominkus M (2005) Prevalence of aneurysmal and solitary bone cysts in young patients. Clinical orthopaedics and related research 439:136-143

8. Schreuder HW, Veth RP, Pruszczynski M, Lemmens JA, Koops HS, Molenaar WM (1997) Aneurysmal bone cysts treated by curettage, cryotherapy and bone grafting. The Journal of bone and joint surgery British volume 79 (1):20-25

9. Kransdorf MJ, Sweet DE (1995) Aneurysmal bone cyst: concept, controversy, clinical presentation, and imaging. AJR American journal of roentgenology 164 (3):573-580. doi:10.2214/ajr.164.3.7863874

10. Papagelopoulos PJ, Choudhury SN, Frassica FJ, Bond JR, Unni KK, Sim FH (2001) Treatment of aneurysmal bone cysts of the pelvis and sacrum. The Journal of bone and joint surgery American volume 83-a (11):1674-1681

11. Novais EN, Zimmerman AK, Lewallen LW, Rose PS, Sim FH, Mclntosh AL (2014) Functional outcomes and quality of life following surgical treatment of aneurysmal bone cysts of the pelvis in children. Journal of children's orthopaedics 8 (3):281-288. doi:10.1007/s11832-014-0588-x

12. Cottalorda J, Chotel F, Kohler R, de Gauzy JS, Louahem D, Lefort G, Dimeglio A, Bourelle S (2005) Aneurysmal bone cysts of the pelvis in children: a multicenter study and literature review. Journal of pediatric orthopedics 25 (4):471-475

13. Liberati A, Altman DG, Tetzlaff J, Mulrow C, Gotzsche PC, loannidis JP, Clarke M, Devereaux PJ, Kleijnen J, Moher D (2009) The PRISMA statement for reporting systematic reviews and meta-analyses of studies that evaluate healthcare interventions: explanation and elaboration. BMJ (Clinical research ed) 339:b2700. doi:10.1136/bmj.b2700

14. Moher D, Liberati A, Tetzlaff J, Altman DG (2009) Preferred reporting items for systematic reviews and meta-analyses: the PRISMA statement. PLoS medicine 6 (7):e1000097. doi:10.1371/journal.pmed.1000097

15. Enneking WF, Dunham WK (1978) Resection and reconstruction for primary neoplasms involving the innominate bone. The Journal of bone and joint surgery American volume 60 (6):731-746

16. Enneking WF (1986) A system of staging musculoskeletal neoplasms. Clinical orthopaedics and related research (204):9-24

17. Rossi G, Rimondi E, Bartalena T, Gerardi A, Alberghini M, Staals EL, Errani C, Bianchi G, Toscano A, Mercuri M, Vanel D (2010) Selective arterial embolization of 36 aneurysmal bone cysts of the skeleton with N-2-butyl cyanoacrylate. Skeletal radiology 39 (2):161-167. doi:10.1007/s00256-009-0757z

18. Brastianos P, Gokaslan Z, McCarthy EF (2009) Aneurysmal bone cysts of the sacrum: a report of ten cases and review of the literature. The lowa orthopaedic journal 29:74-78

19. Capanna R, Bertoni F, Bettelli G, Present D, Biaginil R, Ruggieri P, Mancini I, Campanacci M (1986) Aneurysmal bone cysts of the pelvis. Archives of orthopaedic and traumatic surgery 105 (5):279-284. doi:10.1007/bf00449926

20. Puri A, Agarwal MG, Shah M, Srinivas CH, Shukla PJ, Shrikhande SV, Jambhekar NA (2009) Decision making in primary sacral tumors. Spine Journal 9 (5):396-403. doi:10.1016/j.spinee.2008.10.001

21. Enneking WF, Spanier SS, Goodman MA (1980) A system for the surgical staging of musculoskeletal sarcoma. Clinical orthopaedics and related research (153):106-120

22. Delloye C, De Nayer P, Malghem J, Noel H (1996) Induced healing of aneurysmal bone cysts by demineralized bone particles. A report of two cases. Archives of orthopaedic and trauma surgery 115 (3-4):141-145

23. Docquier P-L, Delloye C (2005) Treatment of Aneurysmal Bone Cysts by Introduction of Demineralized Bone and Autogenous Bone Marrow. JBJS 87 (10):2253-2258. doi:10.2106/jbjs.d.02540

24. Elsayad K, Kriz J, Seegenschmiedt H, Imhoff D, Heyd R, Eich HT, Micke O (2017) Radiotherapy for aneurysmal bone cysts : A rare indication. Strahlentherapie und Onkologie : Organ der Deutschen Rontgengesellschaft [et al] 193 (4):332-340. doi:10.1007/s00066-016-1085-6

25. Sharifah M, Nurhazla H, Suraya A, Tan S (2011) Pelvic aneurysmal bone cyst. Biomedical imaging and intervention journal 7 (4):e24. doi:10.2349/biij.7.4.24

26. van de Luijtgaarden AC, Veth RP, Slootweg PJ, Wijers-Koster PM, Schultze Kool LJ, Bovee JV, van der Graaf WT (2009) Metastatic potential of an aneurysmal bone cyst. Virchows Archiv : an international journal of pathology 455 (5):455-459. doi:10.1007/s00428-009-0845-4

27. Elkattah R, Foulk B (2013) A suspected pelvic aneurysmal bone cyst in pregnancy. Case reports in obstetrics and gynecology $2013: 676087$. doi:10.1155/2013/676087 
28. Issa AA, Amr SS, Swaiss AM Aneurysmal bone cyst of the ilium associated with pregnancy. European Journal of Obstetrics \& Gynecology 23 (3):243-248. doi:10.1016/0028-2243(86)90154-1

29. Hauschild O, Ludemann M, Engelhardt M, Baumhoer D, Baumann T, Elger T, Sudkamp NP, Herget GW (2016) Aneurysmal bone cyst (ABC) : treatment options and proposal of a follow-up regime. Acta Orthop Belg 82 (3):474-483

30. De Cristofaro R, Biagini R, Boriani S, Ricci S, Ruggieri P, Rossi G, Fabbri N, Roversi R (1992) Selective arterial embolization in the treatment of aneurysmal bone cyst and angioma of bone. Skeletal radiology 21 (8):523-527

31. Wallace S, Granmayeh M, deSantos LA, Murray JA, Romsdahl MM, Bracken RB, Jonsson K (1979) Arterial occlusion of pelvic bone tumors. Cancer 43 (1):322-328

32. Varshney MK, Rastogi S, Khan SA, Trikha V (2010) Is sclerotherapy better than intralesional excision for treating aneurysmal bone cysts? Clinical orthopaedics and related research 468 (6):1649-1659. doi:10.1007/s11999-009-1144-8

33. Falappa P, Fassari FM, Fanelli A, Genovese E, Ascani E, Crostelli M, Salsano V, Montanaro A, Di Lazzaro A, Serra F (2002) Aneurysmal bone cysts: treatment with direct percutaneous Ethibloc injection: long-term results. Cardiovascular and interventional radiology 25 (4):282-290. doi:10.1007/s00270001-0062-2

34. Dubois J, Chigot V, Grimard G, Isler M, Garel L (2003) Sclerotherapy in aneurysmal bone cysts in children: a review of 17 cases. Pediatric radiology 33 (6):365-372. doi:10.1007/s00247-003-0899-4

35. Brosjo O, Pechon P, Hesla A, Tsagozis P, Bauer H (2013) Sclerotherapy with polidocanol for treatment of aneurysmal bone cysts. Acta orthopaedica 84 (5):502-505. doi:10.3109/17453674.2013.850013

36. Yu G, Zhang F, Zhou J, Chang S, Cheng L, Jia Y, Li H, Lineaweaver WC (2007) Microsurgical fibular flap for pelvic ring reconstruction after periacetabular tumor resection. Journal of reconstructive microsurgery 23 (3):137-142. doi:10.1055/s-2007-974648

37. Honl M, Westphal F, Carrero V, Morlock M, Schwieger K, Hille E, Delling G (2003) Pelvic girdle reconstruction based on spinal fusion and ischial screw fixation in a case of aneurysmal bone cyst. Sarcoma 7 (3-4):177-182. doi:10.1080/13577140310001644805

38. Mohammed Al Sobeai WAJ (2015) Pelvic Aneurysmal Bone Cyst: Case report and Literature Review. International Journal of Surgical Cases 1 (2):20-25

39. Agha RA, Fowler AJ, Saeta A, Barai I, Rajmohan S, Orgill DP (2016) The SCARE Statement: Consensus-based surgical case report guidelines. International journal of surgery (London, England) 34:180-186. doi:10.1016/j.ijsu.2016.08.014

40. Jackson D, Daly J, Saltman DC (2014) Aggregating case reports: a way for the future of evidence-based health care? Clinical case reports 2 (2):23-24. doi:10.1002/ccr3.58

\section{Tables}

Table 1: Studies and total number of patients included in each treatment group 


\begin{tabular}{|c|c|c|c|c|c|c|}
\hline $\begin{array}{l}\text { Treatment } \\
\text { groups }\end{array}$ & Subgroups & $\begin{array}{l}\text { No. of } \\
\text { studies }\end{array}$ & $\begin{array}{l}\text { Studies included in the systematic } \\
\text { review }\end{array}$ & $\begin{array}{l}\text { Publication } \\
\text { year }\end{array}$ & $\begin{array}{l}\text { No. of pts }{ }^{a} \text { per } \\
\text { study }\end{array}$ & $\begin{array}{l}\text { Total no. of } \\
\text { pts }^{a}\end{array}$ \\
\hline \multirow[t]{5}{*}{ Observation } & - & 5 & McQueen M [41] & 1985 & 2 & 13 \\
\hline & & & Capanna R [19] & 1986 & 3 & \\
\hline & & & Cottalorda[12] & 2005 & 3 & \\
\hline & & & Louahem D [42] & 2012 & 4 & \\
\hline & & & Huschild O [29] & 2016 & 1 & \\
\hline \multirow[t]{22}{*}{ Adjuvant } & $S A E^{b}$ & 11 & Wallace S [31] & 1979 & 1 & 38 \\
\hline & & & Misasi N [43] & 1982 & 2 & \\
\hline & & & Murphy W [44] & 1982 & 1 & \\
\hline & & & Keller F S [45] & 1983 & 2 & \\
\hline & & & Cisneros A J [46] & 1985 & 1 & \\
\hline & & & De Cristofaro R [30] & 1992 & 5 & \\
\hline & & & Rossi G [17] & 2010 & 22 & \\
\hline & & & Rossi G [47] & 2012 & 1 & \\
\hline & & & Doss VT [48] & 2014 & 1 & \\
\hline & & & Soares Do Brito [49] & 2015 & 1 & \\
\hline & & & Saus Milan N [50] & 2016 & 1 & \\
\hline & Sclerotherapy & 5 & Flappa P [33] & 2002 & 1 & 10 \\
\hline & & & Dubios J [34] & 2003 & 1 & \\
\hline & & & Docquier[23] & 2005 & 2 & \\
\hline & & & Bush C H [51] & 2010 & 1 & \\
\hline & & & Brosjo O [35] & 2013 & 5 & \\
\hline & Radiotherapy & 2 & Capanna R [19] & 1986 & 4 & 5 \\
\hline & & & Elsayad K [24] & 2017 & 1 & \\
\hline & SAE ${ }^{b}+$ sclerotherapy & 4 & Dubois J [34] & 2003 & 1 & 4 \\
\hline & & & Docquier[23] & 2005 & 1 & \\
\hline & & & Bush C H [51] & 2010 & 1 & \\
\hline & & & Simm P J [52] & 2013 & 1 & \\
\hline \multirow[t]{13}{*}{ Minor surgery } & Curettage & 9 & Capanna R [19] & 1986 & 11 & 45 \\
\hline & & & Abdullah A I [28] & 1986 & 1 & \\
\hline & & & Papagelopoulos P J [10] & 2001 & 15 & \\
\hline & & & Cottalorda[12] & 2005 & 9 & \\
\hline & & & Brastianos P [18] & 2009 & 2 & \\
\hline & & & Puri A [20] & 2009 & 1 & \\
\hline & & & Ozdemir H M [53] & 2011 & 1 & \\
\hline & & & Huschild O [29] & 2016 & 4 & \\
\hline & & & Elsayad K [24] & 2017 & 1 & \\
\hline & Extended curettage & 4 & Khan A Q [54] & 2010 & 1 & 11 \\
\hline & & & Kim C G [55] & 2014 & 1 & \\
\hline & & & Novais E N [11] & 2014 & 8 & \\
\hline & & & Hetaimish B M [56] & 2016 & 1 & \\
\hline \multirow[t]{3}{*}{ Major surgery } & Marginal excision & 6 & Capanna R [19] & 1986 & 3 & 27 \\
\hline & & & Malghem J [57] & 1989 & 1 & \\
\hline & & & Papagelopoulos P J [10] & 2001 & 17 & \\
\hline
\end{tabular}




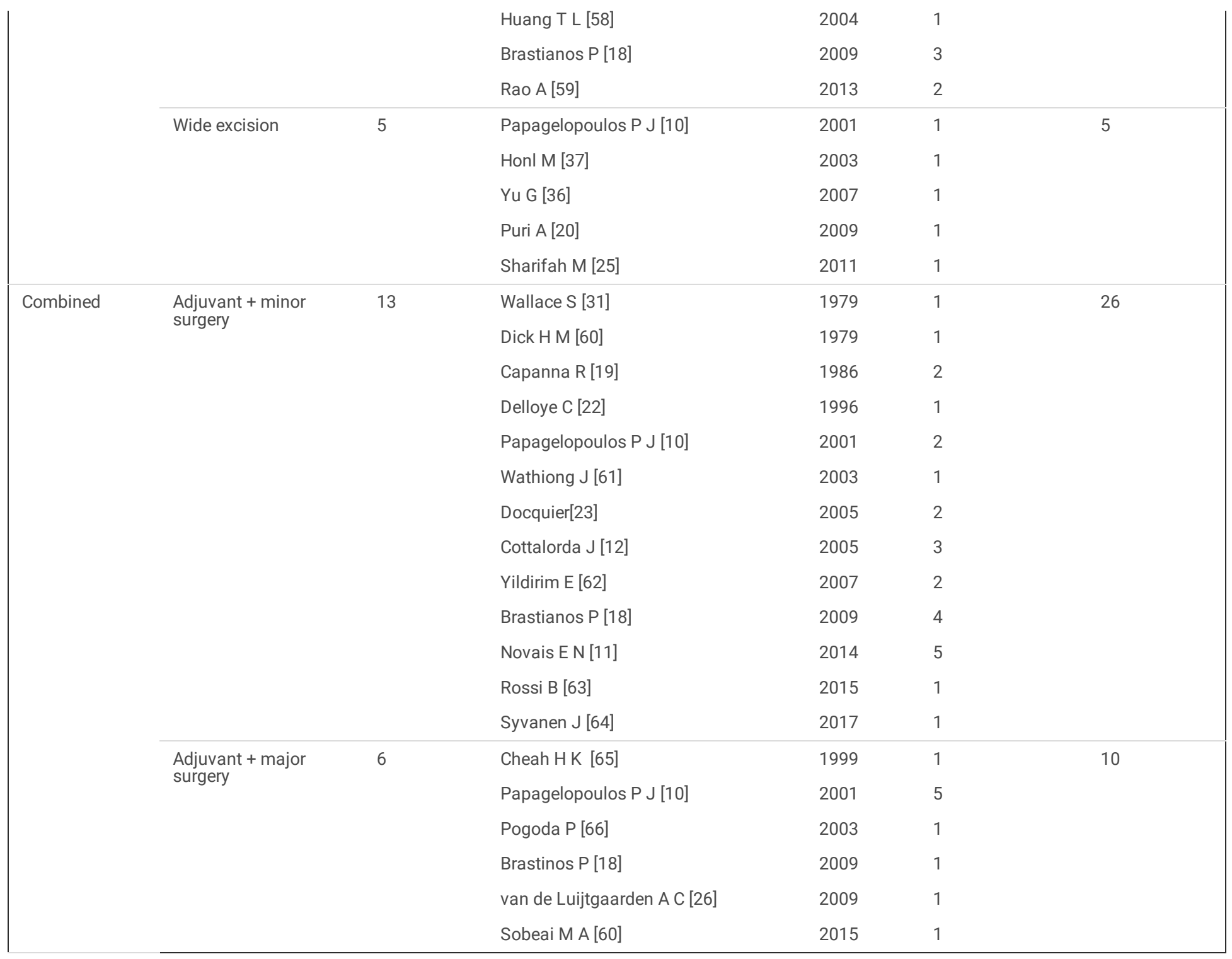

a: Pts = patients, $\mathrm{b}: \mathrm{SAE}=$ selective arterial embolization .

Table 2: Patient characteristics in each treatment group 


\begin{tabular}{|c|c|c|c|c|c|c|c|}
\hline \multirow[t]{3}{*}{ Treatment groups } & \multirow[t]{3}{*}{ Subgroups } & \multirow[t]{3}{*}{ No. of pts ${ }^{a}$} & \multirow{3}{*}{$\begin{array}{l}\text { Median age } \\
(\min -m a x) y^{b}{ }^{b}\end{array}$} & \multirow{2}{*}{\multicolumn{3}{|c|}{$\begin{array}{l}\text { Gender } \\
\mathrm{n}(\%)\end{array}$}} & \multirow{3}{*}{$\begin{array}{l}\text { Median follow up } \\
\text { (min-max) } \text { yrs }^{b}\end{array}$} \\
\hline & & & & & & & \\
\hline & & & & Female & Male & $\mathrm{NR}^{\mathrm{c}}$ & \\
\hline \multirow[t]{2}{*}{ Observation } & - & 13 & 13 & 5 & 8 & - & 2.8 \\
\hline & & & $(10.5-46)$ & $(38 \%)$ & $(62 \%)$ & & $(0.4-11)$ \\
\hline \multirow[t]{8}{*}{ Adjuvant } & $S A E^{d}$ & 38 & 16 & $18(47 \%)$ & 20 & - & 1.75 \\
\hline & & & $(3-33)$ & & $(53 \%)$ & & $(0.6-8)$ \\
\hline & Sclerotherapy & 10 & 13.5 & 5 & 5 & - & 1.5 \\
\hline & & & $(5-28)$ & $(50 \%)$ & $(50 \%)$ & & $(0.9-4.3)$ \\
\hline & Radiotherapy & 5 & 15 & 1 & 4 & - & 7 \\
\hline & & & $(8-22)$ & $(20 \%)$ & $(80 \%)$ & & $(2.1-14)$ \\
\hline & $\mathrm{SAE}^{\mathrm{d}}+$ Sclerotherapy & 4 & 13.5 & 1 & 2 & $1(25 \%)$ & 3.35 \\
\hline & & & $(8-22)$ & $(25 \%)$ & $(50 \%)$ & & $(1.5-5.6)$ \\
\hline \multirow[t]{4}{*}{ Minor surgery } & Curettage & 45 & 15 & $18(40 \%)$ & 27 & - & 5 \\
\hline & & & $(1.5-64)$ & & $(60 \%)$ & & $(1.2-45)$ \\
\hline & Extended curettage & 11 & 13.9 & 5 & 6 & - & 6 \\
\hline & & & $(5-17.5)$ & $(45 \%)$ & $(55 \%)$ & & $(0.6-19.8)$ \\
\hline \multirow[t]{4}{*}{ Major surgery } & Marginal excision & 27 & 14 & $13(48 \%)$ & 14 & - & 7 \\
\hline & & & $(6-60)$ & & $(52 \%)$ & & $(1-42)$ \\
\hline & Wide excision & 5 & 21 & 3 & 2 & - & 11 \\
\hline & & & $(15-51)$ & $(60 \%)$ & $(40 \%)$ & & $(3-19)$ \\
\hline \multirow[t]{4}{*}{ Combined } & Adjuvant + minor surgery & 26 & 13.5 & $17(65 \%)$ & 8 & 1 & 4.5 \\
\hline & & & $(4-38)$ & & $(31 \%)$ & $(4 \%)$ & $(0.6-24)$ \\
\hline & Adjuvant + major surgery & 10 & 16.5 & 5 & 5 & - & 5.25 \\
\hline & & & $(10-57)$ & $(50 \%)$ & $(50 \%)$ & & $(1-53)$ \\
\hline
\end{tabular}

a: pts = patients, b: yrs. = years, $\mathrm{c}$ NR = not reported, $\mathrm{d}: \mathrm{SAE}=$ selective arterial embolization.

Note: Rossi et al[17] grouped the age of patients as $<10,10-20,>20$ yrs. Therefore, these data was excluded when calculating the median age for each treatment group.

Table 3: Tumor characteristics in each treatment group 


\begin{tabular}{|c|c|c|c|c|c|c|c|c|c|c|c|c|c|c|c|}
\hline \multirow[t]{3}{*}{$\begin{array}{l}\text { Treatment } \\
\text { groups }\end{array}$} & \multirow[t]{3}{*}{ Subgroups } & \multirow[t]{3}{*}{$\begin{array}{l}\text { No. } \\
\text { of } \\
\text { pts }^{a}\end{array}$} & \multirow{3}{*}{$\begin{array}{l}\text { * Mean } \\
\text { size } \\
\mathrm{cm}^{\mathrm{b}}\end{array}$} & \multicolumn{10}{|c|}{$\begin{array}{l}\text { Pelvic zone location } \\
\mathrm{n}(\%)\end{array}$} & \multicolumn{2}{|c|}{$\begin{array}{l}\text { Enneking sta } \\
\mathrm{n}(\%)\end{array}$} \\
\hline & & & & \multicolumn{4}{|c|}{ Single zone } & \multicolumn{4}{|c|}{ Two zones } & \multicolumn{2}{|c|}{ Three zones } & & \\
\hline & & & & $1^{\mathrm{c}}$ & $2^{d}$ & $3^{\mathrm{e}}$ & $4^{f}$ & $1+2$ & $1+3$ & $1+4$ & $2+3$ & $1+2+3$ & $1+2+4$ & 1 & 2 \\
\hline Observation & - & 13 & 4.5 & 1 & 1 & 5 & - & - & 1 & - & 1 & 4 & - & 1 & 4 \\
\hline & & & & $(8 \%)$ & $(8 \%)$ & $(38 \%)$ & & & $(8 \%)$ & & $(8 \%)$ & $(30 \%)$ & & $(8 \%)$ & (31 \\
\hline \multirow[t]{6}{*}{ Adjuvant } & SAE ${ }^{h}$ & 38 & 7.3 & 12 & 2 & 15 & 7 & - & - & 2 & - & - & - & & 16 \\
\hline & & & & $(32 \%)$ & $(5 \%)$ & & $(18 \%)$ & & & $(5 \%)$ & & & & - & $(42$ \\
\hline & Sclerotherapy & 10 & 7.68 & 1 & & 3 & 2 & - & 1 & - & 2 & - & - & - & 1 \\
\hline & & & & $(10 \%)$ & & $(30 \%)$ & $(20 \%)$ & & $(10 \%)$ & & $(20 \%)$ & & & & $(10$ \\
\hline & Radiotherapy & 5 & NR & - & - & - & - & - & $\begin{array}{l}3 \\
(60 \%)\end{array}$ & $\begin{array}{l}1 \\
(20 \%)\end{array}$ & - & $\begin{array}{l}1 \\
(20 \%)\end{array}$ & - & - & - \\
\hline & $\begin{array}{l}\mathrm{SAE}^{\mathrm{h}}+ \\
\text { Sclerotherapy }\end{array}$ & 4 & 7.83 & - & - & - & $\begin{array}{l}2 \\
(50 \%)\end{array}$ & - & $\begin{array}{l}1 \\
(25 \%)\end{array}$ & - & - & $\begin{array}{l}1 \\
(25 \%)\end{array}$ & - & - & - \\
\hline \multirow{3}{*}{$\begin{array}{l}\text { Minor } \\
\text { surgery }\end{array}$} & Curettage & 45 & 22.5 & 8 & 2 & 8 & 11 & 2 & 4 & 1 & 4 & 5 & - & 1 & 15 \\
\hline & & & & $(17 \%)$ & $(4 \%)$ & & & $(4 \%)$ & $(8 \%)$ & $(2 \%)$ & $(8 \%)$ & $(11 \%)$ & & $(25 \%)$ & (33 \\
\hline & $\begin{array}{l}\text { Extended } \\
\text { curettage }\end{array}$ & 11 & 11 & $\begin{array}{l}1 \\
(9 \%)\end{array}$ & - & $\begin{array}{l}7 \\
(63 \%)\end{array}$ & & $\begin{array}{l}3 \\
(27 \%)\end{array}$ & - & - & - & - & - & - & $\begin{array}{l}8 \\
(72\end{array}$ \\
\hline \multirow{3}{*}{$\begin{array}{l}\text { Major } \\
\text { surgery }\end{array}$} & Marginal & 27 & 10.8 & 2 & - & 4 & 8 & 2 & 1 & - & & - & - & - & 7 \\
\hline & & & & $(7 \%)$ & & & & $(7 \%)$ & $(10 \%)$ & & $(37 \%)$ & & & & $(26$ \\
\hline & Wide excision & 5 & 18.5 & - & $\begin{array}{l}1 \\
(20 \%)\end{array}$ & - & $\begin{array}{l}1 \\
(20 \%)\end{array}$ & & $\begin{array}{l}1 \\
(20 \%)\end{array}$ & - & $\begin{array}{l}1 \\
(20 \%)\end{array}$ & - & $\begin{array}{l}1 \\
(20 \%)\end{array}$ & - & - \\
\hline \multirow[t]{3}{*}{ Combined } & Adjuvant + & 26 & 7.77 & 2 & 2 & 5 & 6 & 5 & 2 & - & 3 & 1 & - & - & 6 \\
\hline & minor surgery & & & $(8 \%)$ & $(8 \%)$ & & & & $(8 \%)$ & & & $(3 \%)$ & & & $(23$ \\
\hline & $\begin{array}{l}\text { Adjuvant + } \\
\text { major surgery }\end{array}$ & 10 & 21.5 & $\begin{array}{l}1 \\
(10 \%)\end{array}$ & - & $\begin{array}{l}1 \\
(10 \%)\end{array}$ & $\begin{array}{l}4 \\
(40 \%)\end{array}$ & $\begin{array}{l}3 \\
(30 \%)\end{array}$ & - & - & $\begin{array}{l}1 \\
(10 \%)\end{array}$ & - & - & - & $\begin{array}{l}1 \\
(10\end{array}$ \\
\hline
\end{tabular}

a: pts = patients, b: size =mean size of the tumor in centimeters using the maximum dimension reported, c: $1=$ ilium, d: $2=$ acetabulum, e: $3=$ ischio-pubic, $\mathrm{f}: 4$ = sacrum, g: NR =not reported, $\mathrm{h}: \mathrm{SAE}=$ selective arterial embolization.

*Data for tumor size was available for only 50/194 patients.

Table 4: Radiological and clinical outcomes by treatment group 


\begin{tabular}{|c|c|c|c|c|c|c|c|c|c|c|c|c|c|c|}
\hline \multirow[t]{2}{*}{ Treatment } & \multirow[t]{2}{*}{ Subgroups } & \multirow[t]{2}{*}{$\begin{array}{l}\text { No. } \\
\text { of } \\
\text { pts }^{a}\end{array}$} & \multicolumn{4}{|c|}{$\begin{array}{l}\text { Ossification } \\
\text { n (\%) }\end{array}$} & \multicolumn{5}{|c|}{$\begin{array}{l}\text { Functional outcome } \\
\mathrm{n}(\%)\end{array}$} & \multicolumn{3}{|l|}{$\begin{array}{l}\text { Pain } \\
\mathrm{n}(\%)\end{array}$} \\
\hline & & & Yes & Partial & No & $N R^{b}$ & Functional $^{\mathrm{C}}$ & $\begin{array}{l}\text { Mild } \\
\text { FD }^{d}\end{array}$ & $\begin{array}{l}\text { Moderate } \\
\text { FD }^{\mathrm{e}}\end{array}$ & $\begin{array}{l}\text { Severe } \\
\text { FD }^{f}\end{array}$ & $\mathrm{NR}^{\mathrm{b}}$ & $\begin{array}{l}\text { No } \\
\text { pain }\end{array}$ & Mild & Moc \\
\hline $\mathrm{Obs}^{\mathrm{g}}$ & - & 13 & $\begin{array}{l}9 \\
(69 \%)\end{array}$ & $\begin{array}{l}3 \\
(23 \%)\end{array}$ & - & $\begin{array}{l}1 \\
(8 \%)\end{array}$ & $\begin{array}{l}12 \\
(92 \%)\end{array}$ & - & - & - & $\begin{array}{l}1 \\
(8 \%)\end{array}$ & $\begin{array}{l}12 \\
(92 \%)\end{array}$ & - & $\begin{array}{l}1 \\
(8 \%)\end{array}$ \\
\hline \multirow[t]{4}{*}{ Adjuvant } & SAE & 38 & $\begin{array}{l}28 \\
(74 \%)\end{array}$ & $\begin{array}{l}7 \\
(18 \%)\end{array}$ & $\begin{array}{l}3 \\
(8 \%)\end{array}$ & - & $\begin{array}{l}14 \\
(37 \%)\end{array}$ & - & - & - & $\begin{array}{l}24 \\
(63 \%)\end{array}$ & $\begin{array}{l}14 \\
(37 \%)\end{array}$ & - & - \\
\hline & Sclerotherapy & 10 & $\begin{array}{l}10 \\
(100 \%)\end{array}$ & - & - & - & $\begin{array}{l}8 \\
(80 \%)\end{array}$ & - & - & - & $\begin{array}{l}2 \\
(20 \%)\end{array}$ & $\begin{array}{l}8 \\
(80 \%)\end{array}$ & - & - \\
\hline & Radiotherapy & 5 & $\begin{array}{l}4 \\
(80 \%)\end{array}$ & $\begin{array}{l}1 \\
(20 \%)\end{array}$ & - & - & $\begin{array}{l}1 \\
(20 \%)\end{array}$ & - & $\begin{array}{l}2 \\
(40 \%)\end{array}$ & $\begin{array}{l}1 \\
(20 \%)\end{array}$ & $\begin{array}{l}1 \\
(20 \%)\end{array}$ & $\begin{array}{l}2 \\
(40 \%)\end{array}$ & $\begin{array}{l}2 \\
(40 \%)\end{array}$ & $\begin{array}{l}1 \\
(20 \%\end{array}$ \\
\hline & $\begin{array}{l}\mathrm{SAE}^{\mathrm{h}}+ \\
\text { Sclerotherapy }\end{array}$ & 4 & $\begin{array}{l}4 \\
(100 \%)\end{array}$ & - & - & - & $\begin{array}{l}1 \\
(25 \%)\end{array}$ & - & - & - & $\begin{array}{l}3 \\
(75 \%)\end{array}$ & $\begin{array}{l}1 \\
(25 \%)\end{array}$ & - & - \\
\hline \multirow[t]{2}{*}{$\begin{array}{l}\text { Minor } \\
\text { surgery }\end{array}$} & Curettage & 45 & $\begin{array}{l}34 \\
(75 \%)\end{array}$ & $\begin{array}{l}5 \\
(11 \%)\end{array}$ & $\begin{array}{l}1 \\
(2 \%)\end{array}$ & $\begin{array}{l}5 \\
(11 \%)\end{array}$ & $\begin{array}{l}40 \\
(88 \%)\end{array}$ & $\begin{array}{l}2 \\
(4 \%)\end{array}$ & - & $\begin{array}{l}2 \\
(4 \%)\end{array}$ & $\begin{array}{l}1 \\
(2 \%)\end{array}$ & $\begin{array}{l}34 \\
(75 \%)\end{array}$ & $\begin{array}{l}6 \\
(13 \%)\end{array}$ & $\begin{array}{l}1 \\
(2 \%)\end{array}$ \\
\hline & $\begin{array}{l}\text { Extended } \\
\text { curettage }\end{array}$ & 11 & $\begin{array}{l}11 \\
(100 \%)\end{array}$ & - & - & - & $\begin{array}{l}8 \\
(72 \%)\end{array}$ & $\begin{array}{l}1 \\
(9 \%)\end{array}$ & $\begin{array}{l}1 \\
(9 \%)\end{array}$ & - & $\begin{array}{l}1 \\
(9 \%)\end{array}$ & $\begin{array}{l}3 \\
(27 \%)\end{array}$ & - & - \\
\hline \multirow[t]{2}{*}{$\begin{array}{l}\text { Major } \\
\text { surgery }\end{array}$} & $\begin{array}{l}\text { Marginal } \\
\text { excision }\end{array}$ & 27 & $\begin{array}{l}23 \\
(85 \%)\end{array}$ & - & - & $\begin{array}{l}4 \\
(14 \%)\end{array}$ & $\begin{array}{l}22 \\
(81 \%)\end{array}$ & $\begin{array}{l}3 \\
(11 \%)\end{array}$ & & $\begin{array}{l}1 \\
(3 \%)\end{array}$ & $\begin{array}{l}1 \\
(3 \%)\end{array}$ & $\begin{array}{l}19 \\
(70 \%)\end{array}$ & $\begin{array}{l}4 \\
(14 \%)\end{array}$ & - \\
\hline & Wide excision & $5^{\star}$ & $\begin{array}{l}3 \\
(60 \%)\end{array}$ & - & - & $\begin{array}{l}1 \\
(20 \%)\end{array}$ & $\begin{array}{l}2 \\
(40 \%)\end{array}$ & $\begin{array}{l}1 \\
(20 \%)\end{array}$ & - & - & $\begin{array}{l}1 \\
(20 \%)\end{array}$ & $\begin{array}{l}1 \\
(20 \%)\end{array}$ & $\begin{array}{l}1 \\
(20 \%)\end{array}$ & $\begin{array}{l}1 \\
(20 \%\end{array}$ \\
\hline \multirow[t]{2}{*}{ Combined } & $\begin{array}{l}\text { Adjuvant + } \\
\text { minor surgery }\end{array}$ & 26 & $\begin{array}{l}16 \\
(61 \%)\end{array}$ & $\begin{array}{l}3 \\
(11 \%)\end{array}$ & - & $\begin{array}{l}7 \\
(26 \%)\end{array}$ & $\begin{array}{l}15 \\
(57 \%)\end{array}$ & $\begin{array}{l}3 \\
(11 \%)\end{array}$ & $\begin{array}{l}2 \\
(7 \%)\end{array}$ & - & $\begin{array}{l}6 \\
(23 \%)\end{array}$ & $\begin{array}{l}12 \\
(46 \%)\end{array}$ & $\begin{array}{l}1 \\
(3 \%)\end{array}$ & $\begin{array}{l}1 \\
(3 \%)\end{array}$ \\
\hline & $\begin{array}{l}\text { Adjuvant + } \\
\text { major surgery }\end{array}$ & $10 *$ & $\begin{array}{l}8 \\
(80 \%)\end{array}$ & - & $\begin{array}{l}1 \\
(20 \%)\end{array}$ & - & $\begin{array}{l}7 \\
(70 \%)\end{array}$ & $\begin{array}{l}1 \\
(10 \%)\end{array}$ & $\begin{array}{l}1 \\
(10 \%)\end{array}$ & - & - & $\begin{array}{l}6 \\
(60 \%)\end{array}$ & $\begin{array}{l}2 \\
(20 \%)\end{array}$ & - \\
\hline
\end{tabular}

a: pts = patients, b: NR = not reported, c: functional = having full range of motion / activities of daily living / no functional restriction, $\mathrm{d}$ : mild FD = mild functional derangement, e: moderate FD = moderate functional derangement, $\mathrm{f}$ : severe FD: severe functional derangement, $\mathrm{g}$ : obs = observation, $\mathrm{h}$ : $\mathrm{SAE}=$ selective arterial embolization.

*One patient died. Therefore, the sum of the outcomes is less than the total number of patients in these categories.

Table 5: Tumor characteristics and outcomes by pelvic zones 


\begin{tabular}{|c|c|c|c|c|c|c|c|c|c|c|c|c|c|c|c|}
\hline \multirow[t]{2}{*}{$\begin{array}{l}\text { Pelvic } \\
\text { Zones }\end{array}$} & \multirow[t]{2}{*}{$\begin{array}{l}\text { No. } \\
\text { of } \\
\text { pts }^{a}\end{array}$} & \multirow{2}{*}{$\begin{array}{l}\text { \#Mean } \\
\text { size } \\
(\mathrm{cm})^{\mathrm{b}}\end{array}$} & \multicolumn{4}{|c|}{$\begin{array}{l}\text { Enneking stage } \\
\mathrm{n}(\%)\end{array}$} & \multicolumn{4}{|c|}{$\begin{array}{l}\text { Ossification } \\
n(\%)\end{array}$} & \multicolumn{5}{|c|}{$\begin{array}{l}\text { Functional outcome } \\
\mathrm{n}(\%)\end{array}$} \\
\hline & & & 1 & 2 & 3 & $N R^{c}$ & Yes & Partial & No & $\mathrm{NR}^{\mathrm{C}}$ & Functional $^{d}$ & $\begin{array}{l}\text { Mild } \\
\text { FD }^{\mathrm{e}}\end{array}$ & $\begin{array}{l}\text { Moderate } \\
\text { FD }^{f}\end{array}$ & $\begin{array}{l}\text { Severe } \\
\text { FDg }^{\text {g }}\end{array}$ & $\mathrm{NR}^{\mathrm{c}}$ \\
\hline $1 *$ & 28 & 10 & $\begin{array}{l}1 \\
(4 \%)\end{array}$ & $\begin{array}{l}11 \\
(39 \%)\end{array}$ & $\begin{array}{l}10 \\
(36 \%)\end{array}$ & $\begin{array}{l}6 \\
(21 \%)\end{array}$ & $\begin{array}{l}15 \\
(53 \%)\end{array}$ & $\begin{array}{l}10 \\
(35 \%)\end{array}$ & $\begin{array}{l}2 \\
(7 \%)\end{array}$ & - & $\begin{array}{l}14 \\
(50 \%)\end{array}$ & - & - & - & $\begin{array}{l}13 \\
(46 \%)\end{array}$ \\
\hline 2 & 9 & 9.06 & - & $\begin{array}{l}2 \\
(22 \%)\end{array}$ & $\begin{array}{l}6 \\
(67 \%)\end{array}$ & $\begin{array}{l}1 \\
(11 \%)\end{array}$ & $\begin{array}{l}7 \\
(77 \%)\end{array}$ & $\begin{array}{l}1 \\
(11 \%)\end{array}$ & - & $\begin{array}{l}1 \\
(11 \%)\end{array}$ & $\begin{array}{l}8 \\
(88 \%)\end{array}$ & - & - & - & $\begin{array}{l}1 \\
(11 \%)\end{array}$ \\
\hline 3 & 48 & 8.2 & $\begin{array}{l}1 \\
(2 \%)\end{array}$ & $\begin{array}{l}20 \\
(41 \%)\end{array}$ & $\begin{array}{l}19 \\
(40 \%)\end{array}$ & $\begin{array}{l}8 \\
(17 \%)\end{array}$ & $\begin{array}{l}41 \\
(85 \%)\end{array}$ & $\begin{array}{l}4 \\
(8 \%)\end{array}$ & $\begin{array}{l}2 \\
(4 \%)\end{array}$ & $\begin{array}{l}1 \\
(2 \%)\end{array}$ & $\begin{array}{l}36 \\
(75 \%)\end{array}$ & $\begin{array}{l}1 \\
(2 \%)\end{array}$ & $\begin{array}{l}1 \\
(2 \%)\end{array}$ & - & $\begin{array}{l}10 \\
(20 \%)\end{array}$ \\
\hline 4 & 41 & 11.6 & - & $\begin{array}{l}9 \\
(22 \%)\end{array}$ & $\begin{array}{l}26 \\
(63 \%)\end{array}$ & $\begin{array}{l}6 \\
(15 \%)\end{array}$ & $\begin{array}{l}28 \\
(68 \%)\end{array}$ & - & - & $\begin{array}{l}13 \\
(31 \%)\end{array}$ & $\begin{array}{l}23 \\
(56 \%)\end{array}$ & $\begin{array}{l}6 \\
(15 \%)\end{array}$ & - & $\begin{array}{l}3 \\
(7 \%)\end{array}$ & $\begin{array}{l}9 \\
(21 \%)\end{array}$ \\
\hline $1+2$ & 15 & 7.5 & - & $\begin{array}{l}5 \\
(33 \%)\end{array}$ & $\begin{array}{l}10 \\
(67 \%)\end{array}$ & - & $\begin{array}{l}13 \\
(86 \%)\end{array}$ & - & - & $\begin{array}{l}1 \\
(6 \%)\end{array}$ & $\begin{array}{l}9 \\
(60 \%)\end{array}$ & $\begin{array}{l}4 \\
(26 \%)\end{array}$ & $\begin{array}{l}1 \\
(6 \%)\end{array}$ & - & $\begin{array}{l}1 \\
(6 \%)\end{array}$ \\
\hline $1+3 *$ & 14 & 15.5 & - & $\begin{array}{l}4 \\
(29 \%)\end{array}$ & $\begin{array}{l}10 \\
(71 \%)\end{array}$ & - & $\begin{array}{l}11 \\
(78 \%)\end{array}$ & $\begin{array}{l}1 \\
(7 \%)\end{array}$ & $\begin{array}{l}1 \\
(7 \%)\end{array}$ & - & $\begin{array}{l}8 \\
(57 \%)\end{array}$ & - & $\begin{array}{l}1 \\
(7 \%)\end{array}$ & $\begin{array}{l}1 \\
(7 \%)\end{array}$ & $\begin{array}{l}3 \\
(21 \%)\end{array}$ \\
\hline $1+4$ & 4 & $N^{c}$ & - & $\begin{array}{l}1 \\
(25 \%)\end{array}$ & $\begin{array}{l}2 \\
(50 \%)\end{array}$ & $\begin{array}{l}1 \\
(25 \%)\end{array}$ & $\begin{array}{l}3 \\
(75 \%)\end{array}$ & $\begin{array}{l}1 \\
(25 \%)\end{array}$ & - & - & $\begin{array}{l}3 \\
(75 \%)\end{array}$ & - & - & - & $\begin{array}{l}1 \\
(25 \%)\end{array}$ \\
\hline $2+3$ & 22 & 7.75 & - & $\begin{array}{l}5 \\
(23 \%)\end{array}$ & $\begin{array}{l}17 \\
(77 \%)\end{array}$ & - & $\begin{array}{l}21 \\
(95 \%)\end{array}$ & $\begin{array}{l}1 \\
(5 \%)\end{array}$ & - & - & $\begin{array}{l}21 \\
(95 \%)\end{array}$ & - & $\begin{array}{l}1 \\
(5 \%)\end{array}$ & - & - \\
\hline $1+2+3$ & 12 & 11 & - & $\begin{array}{l}2 \\
(17 \%)\end{array}$ & $\begin{array}{l}10 \\
(83 \%)\end{array}$ & - & $\begin{array}{l}8 \\
(66 \%)\end{array}$ & $\begin{array}{l}1 \\
(8 \%)\end{array}$ & - & $\begin{array}{l}3 \\
(25 \%)\end{array}$ & $\begin{array}{l}8 \\
(66 \%)\end{array}$ & - & $\begin{array}{l}1 \\
(8 \%)\end{array}$ & - & $\begin{array}{l}3 \\
(25 \%)\end{array}$ \\
\hline $1+2+4$ & 1 & $\mathrm{NR}^{\mathrm{c}}$ & - & - & $\begin{array}{l}1 \\
(100 \%)\end{array}$ & - & $\begin{array}{l}1 \\
(100 \%)\end{array}$ & - & - & - & - & - & - & - & $\begin{array}{l}1 \\
(100 \%\end{array}$ \\
\hline
\end{tabular}

a: pts = patients, b: mean size of the tumor in centimeters using the maximum dimension reported, $\mathrm{c}$ : NR= no reported, d: functional = having full range of motion / activities of daily living / no functional restriction, e: mild FD = mild functional derangement, f: moderate FD = moderate functional derangement, g: severe FD: severe functional derangement.* One patient died. Therefore, the sum of the outcomes is less than the total number of patients in these categories. \#Data for tumor size was available for only $50 / 1$

\section{Figures}




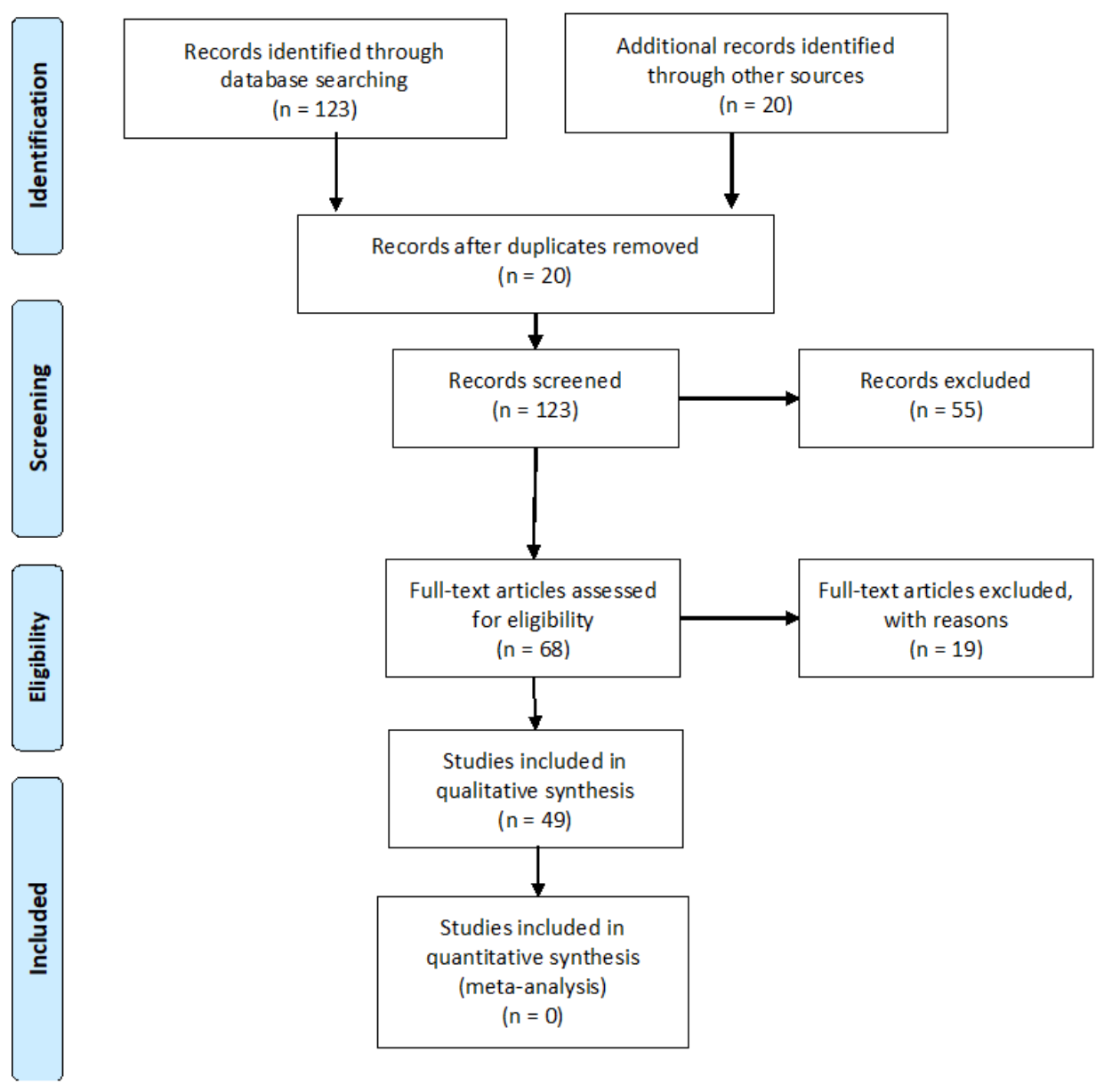

\section{Figure 1}

Flow diagram to explain the methodology of systematic review of pelvic aneurysmal bone cyst.

\section{Supplementary Files}

This is a list of supplementary files associated with this preprint. Click to download.

- PRISMA2009checklistforsystematicreviews.doc 